\title{
TINJAUAN HERMENEUTIKA GADAMERIAN TERHADAP PERGESERAN PARADIGMA TAFSIR PEREMPUAN DI INDONESIA
}

\author{
Munirul Abidin
}

\author{
Email: munirulabidin@yahoo.com
}

Fakultas Sains dan Teknologi Universitas Islam Negeri Maulana Malik Ibrahim Malang

Alamat Korepondensi: Jalan Gajayana 50 Malang 65144

\begin{abstract}
This research aims to find out the paradigm shifting of Qur'anic interpretation on woman verses from Gadamerian perspective. This writing finds out three paradigms: classical, modern and neomodernism paradigm. Each paradigm has its own world view that necessary to its context. From Gadamerian perspective, the emergence of those three paradigms in Qur'anic interpretation about woman verses is necessity. As a text, Qur'an is not a dead object, but it will be understood by people from different point of views. In interpreting a text, an instrument is used to help finding out the right interpretation. Interpretation is not a hall of mirrors in which interpreters only see themselves in different poses and shapes depending on the shape and angle of the mirror which confronts them. Rather, interpretation is a process of listening to others through their words and deeds.
\end{abstract}

\section{Keywords}

Hermeneutika, Gadamerian, Tafsir Perempuan

\section{Pendahuluan}

Di Indonesia kajian tentang perempuan dan gender mendapat sambutan yang sangat baik. Sejak tahun 90-an, literatur dan kajian tentang prempuan digalakkan sehingga memunculkan sejumlah peneliti seperti Mansour Fakih, Masdar Mas'udi, Nurul Agustina dan sebagainya, yang mencoba menelusuri lebih lanjut berbagai macam literatur, baik klasik maupun modern yang ada kaitannya dengan masalah perempuan. Salah satu bidang yang menjadi titik perhatian mereka adalah kitab kuning khususnya tafsir AlQur'an.

Dari hasil pelacakan peneliti terhadap beberapa literatur yang membahas tentang masalah tafsir perempuan, paling tidak ada dua pendapat yang berseberangan:

Pertama, mereka yang berpendapat bahwa seluruh kajian tafsir Al-Qur'an, baik klasik maupun modern, melihat perempuan lebih rendah dari laki-laki dan ayat-ayat tentang perempuan ditafsirkan secara sepihak oleh lakilaki sehingga menyebabkan bias gender dan perlu ditafsirkan ulang agar sesuai dengan situasi dan kondisi masyarakat yang terus berkembang.
Kedua, mereka yang berpendapat bahwa para penafsir telah mendudukkan perempuan pada posisinya yang luhur tanpa diskriminasi. Para mufassir telah berusaha menafsirkan ayat-ayat Al-Qur'an itu sesuai dengan apa yang diinginkan oleh Al-Qur'an itu sendiri, bukan seperti apa yang dimaui oleh manusia.

Kedua pendapat di atas, memiliki pendukung sendiri-sendiri dari kalangan yang berbeda-beda. Pendapat pertama biasanya didukung oleh para tokoh feminis Muslim dan aktivis perempuan muslim, sedangkan pendapat kedua didukung oleh para tokoh intelektual yang pemikirannya bercorak totalistik (Syafi'i Anwar, 1995: 145).

Ditinjau dari perspektif analisis bahasa, AlQur'an sebagai teks, bias mengundang banyak interpretasi. Tuhan sebagai pencipta teks, telah mengeluarkan suatu teks yang bisa difahami oleh pembacanya dengan pemahaman yang berbedabeda. Demikian itu terjadi, karena dalam kacamata hermeneutika Romantis Schleiermacher dikatakan bahwa penafsiran bertugas untuk merekonstruksi pikiran pengarang. Tujuan pemahaman bukan makna yang diperoleh dari dalam materi subyek, tetapi lebih merupakan makna yang muncul dalam pandangan pengarang yang telah direkonstruksi tersebut. Jadi interpretasi yang benar, menurut Schleilmacher, tidak saja melibatkan pemahaman 
konteks kesejarahan dan budaya pengarang, tetapi juga pemahaman terhadap subjektivitas pengarang (Zarkasyi, 2004: 25).

Menurut perspektif ini, ada lima unsur yang terlibat dalam upaya memahami wacana atau teks (Thiselton, 1992: 204-205). Masing-masing adalah penafsir, teks, maksud pengarang, konteks historis, dan konteks kultural. Penafsir yang hendak memahami suatu wacana selain mencermati teks, juga meletakkannya dalam konteks histories. Makna teks, sejauh mengikuti perspektif ini, diidentikkan dengan maksud pengarang. Dengan demikian, bagi Schleiermacher, di samping faktor gramatikal (tata bahasa), faktor kondisi dan motif pengarang sangat penting untuk memahami makna suatu teks (Gadamer, 1977: xiii).

Berangkat dari latar belakang di atas, maka ada dua persoalan yang akan dijawab dalam penelitian ini. Pertama, apa saja betuk-bentuk paradigma penafsiran Al-Qur'an tentang perempuan di Indonesia? Kedua, mengapa berbagai corak paradigma Tafsir itu muncul, faktor-faktor apa saja yang menyebabkannya bila ditinjau dari kacamata hermeneutika gadamerian?

\section{Metode}

Ancangan dasar kajian ini adalah fenomenologi linguistik. Berbeda dari tradisi positivistik yang cenderung menjelaskan perilaku manusia, tradisi fenomenologi hemeneutik cenderung mengedepankan manusia sebagai sesuatu yang harus ditafsirkan. Namun demikian, karena kajian ini tidak bertujuan memahami teks sebagaimana dipahami oleh pembuatnya, tetapi oleh para penafsir teks tersebut, maka perspektif yang digunakan bukan hermeneutika intensional Hirschian, melainkan hermeneutika Gadamerian.

Dalam Perspektif hermeneutika Gadamerian (Fay, 1996) wacana bukan pada maksud (intention) penutur seperti pada hermeneutika intensionalisme (pragmatics) atau Hirschian, tetapi pada penerimaan (perception) pendengar atau pembaca. Walaupun suatu waacana atau teks diproduksi oleh seseorang, sesuai dengan hakikat bahasa, teks atau wacana tidak ditujukan kepada diri penutur atau penulis sendiri. Wacana dipandang sebagai sesuatu yang otonom, yang sudah terlepas dari penyampainya. Senada dengan pendapat ini, seorang penganut poststrukturalisme, Piliang (1999: 70) memandang pengarang teks tidak lagi hadir dalam wacana: pengarang tak lagi bicara. Dalam istilah yang dipopulerkan oleh Barthes (1977), "The outhor is dead", atau pembuat teks telah mati, karena setelah dia mengeluarkan teks maka bahasalah yang bicara.

Dalam analisis teks, Barthes dengan tegas mengingatkan bahwa teks bukan untaian katakata yang siap melepaskan makna tunggalnya semata, yaitu pesan dari sang penciptanya saja, tetapi berasal dari ruang multidimensi yang ada tersebar dalam tulisan. "Teks tidak lain merupakan sejumlah kutipan yang tergambar dari pusat-pusat budaya yang jumlahnva tidak terbatas. (Barthes, 1977: 146).

Hal penting yang harus diperhatikan bagi pengkaji hermeneutika Gadamerian menurut Barthes adalah teks akan dikupas maknanya jauh lebih dalam daripada penciptanya sendiri. Otoritas sebuah tulisan berada di tangan pembaca, bukan lagi di tangan pembuat teks (Fasya, 2002: 43).

Data kajian ini bersumber dari Kitab-kitab tafsir yang ditulis oleh para mufassir Indonesia, bukubuku yang membahas tentang masalah perempuan dan juga dokumen-dokumen lain yang membahas atau menafsirkan tentang ayatayat perempuan dalam Al-Qur'an. Di antara kitab-kitab tafsir Indonesia yang kami jadikan sebagai sumber primer dalam penelitian ini adalah Tafsir Al-Azhar karya Hamka dan tafsir Qur'an Karim karya Mahmud Yunus. Sedangkan sumber lainnya diambil dari buku-buku lain yang berbicara tentang masalah perempuan yang telah diseleksi.

Satuan kajian atau unit analisis tulisan ini adalah wacana tulis dari para mufassir Indonesia di atas, yang berupaya memahami ayat-ayat Al-Qur'an tentang perempuan, khususnya surat An-Nisa' ayat empat yang berbunyi: "Ar-Rijaalu Qawwamun 'ala An-Nisa'."

Para mufassir Indonesia yang saya sebutkan di atas, memiliki lokus dan tempus sendiri-sendiri ketika berhadapan dengan teks, sehingga dapat mewakili posisi mereka masing-masing dalam menafsirkan teks tersebut.

Dengan mengacu pada hasil pembahasan terhadap asumsi, konsepsi, dan strategi hermeneutika Gadamerian, secara berturut-turut penulis mengembangkan langkah operasional sebagai berikut:

Langkah pertama, mengumpulkan teks-teks atau wacana tertulis yang terpublikasikan (published discourse), baik dalam kitab-kitab tafsir, bukubuku, journal maupun tulisan-tulisan lain yang ditulis oleh para mufassir Indonesia kontemporer tentang masalah perempuan dan 
penafsiran terhadap ayat-ayat tentang peran perempuan, khususnya surat An-Nisa' ayat 4 yang berbunyi, "Ar-Rijaalu qawwamun 'ala annisa'." Langkah kedua, penetapan wacana interaktif (interactive discourse) ini harus dilakukan karena, sesuai dengan pilihan perspektif hermeneutika Gadamerian yang menegaskan bahwa makna merupakan produk interaksi antara dua subjek, penulis berusaha mengungkap makna wacana bukan berdasarkan pemahaman penutur atau penulis, melainkan justru menurut pasangan interaksinya. Langkah ketiga, menelusuri dan menelaah penafsiran para mufassir Indonesia pendahulu yang dilanjutkan dengan penafsiran yang datang berikutnya, yang merupakan counter terhadap penafsiran sebelumnya. Setelah itu akan dilakukan penelaahan dan penelusuran proses diadik pemaknaan. Langkah keempat, menelaah dan mengungkap keserba-maknaan wacana. Langkah kelima, mengembangkan pemahaman teoretik substantif.

Secara garis besar terdapat keterbatasan metodologis dalam kajian ini. Keterbatasan metodologis terkait dengan kelemahan empirik dan hermeneutik. Keterbatasan empirik berkenaan dengan pengumpulan dan penentuan data. Akan tetapi, untuk mempermudah peneliti menetapkan nama-nama kitab dan buku-buku tertentu yang dijadikan sebagai sumber primer, lalu ditambah dengan rujukan-rujukan lain yang ditemukan belakangan untuk mendukung datadata yang diperoleh pada sumber-sumber primernya.

\section{Temuan dan Diskusi}

Secara umum ditemukan bahwa perkembangan isu-isu gender dalam tafsir, dapat diklasifikasikan menjadi tiga paradigma yang berbeda; yaitu paradigma klasik tradisional, paradigma modern dan paradigma neo-modern.

\section{Pandangan Tafsir Klasik: Inferioritas Kaum Perempuan.}

Dalam menanggapi isu-isu gender, karya tafsir Indonesia yang berparadigma klasik ini, kebanyakan kalau tidak seluruhnya, bersifat pasif, artinya mereka hanya menafsirkan ayatayat tersebut apa adanya sesuai dengan pemahaman literal terhadap ayat-ayat gender yang ada, dan bersifat atomistik, tanpa mengaitkannya dengan unsur-unsur sosial lainnya. Kelemahan lain dari tafsir semacam ini adalah kurang luasnya wawasan penafsiran terhadap ayat-ayat Al-Qur'an, sehingga pemahamannya bersifat parsial dan tidak komprehensif. Karena itu dalam menafsirkan ayat-ayat perempuan, tafsir yang berparadigma klasik-tradisional ini, seakan-akan, bersifat dikriminatif, bahwa laki-laki lebih kuaat dan lebih unggul dari perempuan dalam berbagi bidang. Akibat lebih lanjut dalam pandangan tafsir berparadigma klasik ini, perempuan dianggap inferior dan laki-laki dianggap superior. Pandangan semacam in berawal dari cara memahami dan menafsirkan surah $\quad$ 4:34) yang artinya: "Kamu laki-laki itu adalah "qawwâmun" bagi kaum perempuan..."

Hamka (1982) dalam tafsir Al-Azhâr menafsirkan kata "qawwâmun" ini dengan pemimpin, sehingga pengertian hamka mengenai ayat ini adalah bahwa laki-laki pemimpin bagi perempuan. Begitu pula Mahmud Yunus (1993: 117), juga menafsirkan kata "qawwâmun" itu dengan pemimpin. Penafsiran semacam ini pada gilirannya akan mengakibatkan munculnya penilaian dalam tafsir klasik-tradisional bahwa kaum laki-laki mempunyai potensi yang lebih dibandingkan dengan kaum perempuan, sehingga kaum laki-laki harus menjadi pemimpin bagi wanita dalam segala bidang, baik di dalam rumah tangga maupun di bidang-bidang lainnya.

Pandangan lain yang mencerminkan pandangan klasik bahwa laki-laki lebih superior dari perempuan adalah dalam penafsiran terhadap surat Al-Baqarah: 22 yang artinya: "Hai orangorang yang beriman, apabila kamu bermuamalah tidak secarai tunai untuk waktu yang ditentukan, hendaklah kamu menuliskannya.......Dan persaksikanlah dengan dua orang saksi dari orang-orang pria di antaramu. Juka tidak ada dua orang pria, maka (boleh) seorang pria dan dua orang wanita dari saksi-saksi yang kamu ridhai, supaya jika seorang lupa maka seorang lagi mengingatkannya...".

Para penafsir Indonesia yang berparadigma tradisional menafsirkan ayat di atas dengan metode penafsiran tekstual, yaitu mereka memberikan sedikit penjelasan rasional tentang makna ayat, namun tanpa mengaitkannya dengan situasi dan kondisi masyarakat Arab ketika ayat itu diturunkan. Menurut ayat ini, persaksian minimal dilakukan oleh dua orang pria Muslim atau jika tidak ada, boleh dilakukan oleh satu pria dan dua orang wanita. Secara literal, ayat di atas membedakan antara persaksian kaum pria dan kaum wanita. Dalam menafsirkan ayat ini Mahmud Yunus mengatakan, bahwa ketentuan saksi pria hanya seorang sedangkan wanita dua orang. Alasan yang dipakai Mahmud Yunus, karena masalah hutang piutang dalam perniagaan, biasanya adalah persoalan pria, bukan urusan kaum wanita sehingga wanita tidak begitu mementingkannya. Oleh sebab itu, kerap 
kali wanita lupa dalam urusan ini, sehingga harus dua orang wanita.

\section{Paradigma Modern: Upaya mencari tafsir gender yang adil.}

Menurut Barbara Stowasser (1998: 33-34), paradigma modern dalam kajian tafsir perempuan, biasanya sudah menggunakan metode tematis dalam menafsirkan ayat-ayat AlQur'an tentang perempuan, sehingga kesimpulan yang diambilnya sudah agak berbeda dengan paradigma tradisionalis di satu sisi, namun di sisi lain penafsiran model ini masih terkesan bersifat reaktif baik terhadap perkembangan dunia modernitas maupun terhadap perkembangan tafsir sebelumnya, tradisionalis, sehingga kadang-kadang kurang memperhatikan sebuah penafsiran yang utuh dan komprehensif, walaupun toh sudah ada yang agak mendekatinya.

Di Indonesia, penafsiran model ini telah muncul sejak akhir tahun 1990-an, dengan hadirnya beberapa penafsir yang telah mengenal penafsiran modern dan mereka yang telah dipengaruhi oleh gerakan feminisme. Di antara penafsir Indonesia yang membahas tentang perempuan dalam paradigma modern ini adalah M. Quraish Shihab. Dalam bukunya yang berjudul Membumikan Al-Qur'an, Quraish Shihab, dengan menggunakan metode tematik, membahas masalah perempuan yang ditinjau dari aspek kedudukan, hak dan kewajibannya dalam suatu kajian yang hampir sempurna. Dalam kajiannya tersebut sebelum sampai pada penafsirannya sendiri Quraish Shihab banyak mengutip pendapat-pendapat dari para mufassir modern. Ia mengatakan bahwa kedudukan perempuan dalam pandangan Islam tidak sebagaimana diduga atau dipraktekkan sementara masyarakat. Ajaran Islam pada hakikatnya memberikan perhatian yang sangat besar serta kedudukan terhormat kepada perempuan.

Mengenai asal kejadian perempuan, Quraish Shihab menyangkal pendapat yang mengatakan bahwa perempuan diciptakan dari tulang rusuk laki-laki. Berdasarkan ayat Al-Qur'an Surat AnNisa': 1 yang artinya, "Hai sekalian manusia, bertakwalah kepaa tuhanmu yang telah menciptakan kamu dari jenis yang sama dan darinya Allah menciptakan pasangannya dan dari keduanya Allah memperkembangbiakkan lelaki dan perempuan yang banyak."

Kata "nafsun wahidah" dalam ayat ini diartikan Quraish Shihab (1999) dengan "jenis yang sama". Penafsiran ini tentu sangat berbeda dengan penafsiran atau penerjemahan yang beredar di
Indonesia sebelumnya, seperti dalam tafsir Hamka, Hasbi dan Mahmud Yunus, ketiga penafsir itu menerjemahkan kata "nafsun wahidah" dengan "seorang diri" yang kemudian dikonotasikan dengan Adam. Quraish Shihab (1999: 272) juga menyangkal penafsiran klasik yang mengatakan bahwa wanitalah yang menjadi penyebab tergelincirnya Adam dari surga dan akhirnya dilemparkan ke dunia ini. Menurutnya bahwa ayat yang menjelaskan tentang ketergelinciran Adam dan Hawa dibentuk dalam kata yang menunjukkan kebersamaan keduanya tanpa perbedaan. Untuk menguatkan pendapatnya, Quraish Shihab mengutip beberapa ayat Al-Qur'an seperti Q.S 7:20 yang artinya, "maka syetan membisikkan pikiran kepada keduanya..." dan Q.S. 2:36 yang artinya: "Lalu keduanya digelincirkan oleh syetan dari surga itu dan keduanya dikeluarkan dari keadaan yang mereka nikmati sebelumnya..." dari kedua ayat tersebut di atas Quraish Shihab berpendapat bahwa Al-Qur'an mendudukkan perempuan pada tempat yang sewajarnya serta meluruskan segala pandangan yang salah dan keliru yang berkaitan dengan kedudukan dan asal kejadiannya.

Langkah Quraish Shihab ini kemudian disambut baik oleh kalangan akademisi khususnya yang telah mengenal gerakan feminisme di dunia Barat. Di antaranya adalah Didin Syarifuddin, seorang dosen bahasa Arab di IAIN Syrif Hidayatullah Jakarta. Didin dalam sebuah artikel yang dimuat dalam Ulumul Qur'an menyatakan,

Sekarang setelah adanya komunikasi dengan dunia Barat, perluasan pendidikan modern, perlindungan hukum dan perubahan struktur sosial, ekonomi maupun politik sejak awal abad ke-20, fantasi para mufassir tentang superioritas laki-laki atas perempuan semakin mudah untuk ditolak. Dalam kecerdasan, prestasi di sekolahsekolah, lembaga-lembaga riset maupun di dunia menejemen, kaum perempuan semakin menonjol. Dalam ketaatan beragama mereka juga menonjol. Terbukti majlis-majlis ta'lim selalu dipenuhi kaum ini. Tidak sedikit dari kaum perempuan muncul pula para muballighat kondang. Kemudian kaum perempuan sekarang banyak aktif di dunia kegiatan yang menuntut ketahanan fisik seperti angkat besi, bina raga, menjadi sopir truk atau bus, menjadi tentara, polisi atau penerbang. Mereka ini secara fisik bisa mengalahkan laki-laki seperti dalam filmfilm Hongkong atau Barat. Kelebihan perempuan secara politis dan ekonomis sudah bukan merupakan pemandangan aneh. Secara ekonomis, bukan dongeng bila posisi pemberi mahar dan biaya pesta pernikahan ataupun belanja keluarga tidak lagi dimonopoli laki-laki. Istri misalnya mejadi tulang punggung ekonomi 
keluarga dengan membuka konveksi atau warung nasi sementara laki-laki menganggur. Dengan demikian, perkembangan dewasa ini membuktikan bahwa keunggulan atas dasar gender hanyalah mitos karena faktanya superioritas itu bersifat relatif sangat tergantung pada usaha pribadi laki-laki dan perempuan tersebut" (Ulumul Qur'an, Vol. 5, 1994: 7-8)

\section{Paradigma Neo Modern: Persamaan Antara Laki-laki dan Perempuan.}

Menurut pandangan tafsir yang berparadigma Neo Modern, tidak ada perbedan yang substansial antara laki-laki dan perempuan dalam Al-Qur'an. Kalaupun Al-Qur'an membedakan laki-laki dan perempuan, pembedaan itu hanya dari aspek fungsional saja, yang mana itupun masih sangat bersifat kondisional dan tidak mutlak.

Menurut Barbara Stowasser (1998: 33-34), paradigma Neomodern dalam kajian tafsir perempuan, biasanya menggunakan metode holistic yang mengandung unsur metode tematik, hermeunitik, dan historis. Sedangkan pendekatan yang digunakan bersifat kontekstual, yaitu menyesuaikan situasi dan kondisi perkembangan masyarakat.

Di antara penafsir Indonesia yang dapat dikategorikan ke dalam paradigma ini adalah Dr. Nasaruddin Umar, pembantu Rektor IV IAIN Syarif Hidayatullah Jakarta 1998-2002. Dalam bukunya yang berjudul Argumen Kesetaraan Gender Perspektif Al-Qur'an berupaya mengeksplorasi konsep gender dalam Al-Qur'an dengan menggunakan pendekatan yang holistik tersebut. Dalam bukunya itu Nasaruddin (1999: 7) mengkritik konsepsi gender yang selama ini di antara teori-teori yang ada itu yang melibatkan nilai-nilai agama sebagai salah satu unsur pertimbangannya, padahal nilai-nilai agama merupakan salah satu unsur penting di dalam kehidupan masyarakat. Atas dasar inilah ia melakukan penulisan buku tersebut.

Dalam penelitiannya ini, Nasaruddin mencoba untuk melacak kembali konsep gender dalam AlQur'an. Dalam hal ini ia kembali kepada kata dasar rijal dan nisa' dalam Al-Qur'an untuk mengetahui posisi masing-masing jenis kelamin itu dalam Al-Qur'an. Setelah itu Nasaruddin menarik pembahasannya pada pencarian hakikat dan substansi kejadian manusia. Dari sini Nasaruddin Umar menemukan lima prinsip yang bisa dijadikan sebagai pijakan bagi konsep kesetaraan gender dalam Al-Qur'an.

Pertama, laki-laki dan perempuan sama-sama sebagai hamba (Q.S. 16:97). Kedua, laki-laki dan perempuan sama-sama sebagai khalifah di bumi (Q.S. 2:30). Ketiga, laki-laki dan perempuan sama-sama menerima perjanjian premodial (Q.S. 7:172). Keempat, Adam dan Hawa, sama-sama terlibat aktif dalam drama kosmis (Q.S. 2:35), (b) keduanya mendapat kualitas godaan yang sama dari syaitan (Q.S. 7:20), (c) keduanya sama-sama memakan buah khuldi dan menerima akibat jatuh ke bumi (Q.S. 7:22), keduanya sama-sama memohon ampun dan sama-sama diampuni Tuhan (Q.S. 7:23), (e) setelah di bumi, keduanya mengembangkan keturunan dan saling melengkapi dan saling membutuhkan (Q.S. 2:187). Kelima, laki-laki dan perempuan berpotensi meraih pestasi (An-Nahl: 97).

Dari ketiga paradigma di atas dapat disimpulkan ke dalam table 1 sebagai berikut:

Tabel 1 . Pergeseran Paradigma Tafsir Perempuan di Indonesia.

\begin{tabular}{|c|c|c|c|c|}
\hline No. & Kategori & $\begin{array}{l}\text { Paradigma } \\
\text { Tradisional } \\
\end{array}$ & Paradigma Modern & $\begin{array}{c}\begin{array}{c}\text { Paradigma Neo } \\
\text { Modern }\end{array} \\
\end{array}$ \\
\hline 1 & Metode & Atomistik & Tematik & $\begin{array}{l}\text { Holistik: tematik, } \\
\text { hermeunitik, historis }\end{array}$ \\
\hline 2 & Pendekatan & Tektual & Kontekstual & Kontekstual \\
\hline 3 & $\begin{array}{l}\text { Sikap adaptasi } \\
\text { terhadap modernitas }\end{array}$ & Pasif & Kritis-reaktif & Kritis-analitis \\
\hline 4 & Hasil penafsiran & Parsial & Semi komprehensif & Komprehensif \\
\hline 5 & $\begin{array}{l}\text { Pandangan terhadap } \\
\text { perempuan. }\end{array}$ & $\begin{array}{l}\text { Kedudukan perempuan } \\
\text { lebih rendah dari laki- } \\
\text { laki. }\end{array}$ & $\begin{array}{l}\text { Kedudukan perempuan } \\
\text { hampir sama dengan } \\
\text { laki-laki. }\end{array}$ & $\begin{array}{l}\text { Kedudukan } \\
\text { perempuan sama } \\
\text { dengan laki-laki. }\end{array}$ \\
\hline
\end{tabular}

difahami oleh para pemikir Barat dan umat Islam sendiri. Ia prihatin dengan banyaknya teori tentang gender, tetapi teori dari Islam itu sendiri belum ada. Ia juga prihatin bahwa tidak satu pun

\section{Relativitas tafsir gender.}

Sebelum kita melangkah lebih jauh, mungkin muncul pertanyaan dalam pikiran para 
pembaca, mengapa dalam konteks Indonesia kontemporer terjadi pergeseran paradigma dalam menafsirkan ayat-ayat perempuan?

Penjelasan yang diberikan oleh hermeneutika Gadamerian tentang masalah ini cukup jelas, bahwa tidak bisa ada pemahaman tunggal terhadap apa yang dikemukakan oleh teks kitab suci termasuk Al-Qur'an. Mengapa hal itu terjadi? Dalam hal ini Littlejohn (1992: 221) menjelaskan tentang teori Gadamer,

"For Gadamer, individuals do not stand apart from texts in order to analyze and interpret them; rather, interpretation itself is part and parcel of being. The central tenet of Gadamer's theory is that one always understand experience from the perspective of presuppositions. Our tradition give us a way of understanding thing, and we cannot divorce ourselves from that tradition. Observation, reason, and understanding are never objectively pure; they are colored by history and community. Further, history is not to be separated from the present". (Littlejohn, 1992: 221).

Inti dari teori Gadamer di atas bahwa dalam memahami atau menafsirkan sebuah teks, seseorang tidak bisa lepas atau menjauh dari teks itu sendiri. Observasi, alasan dan pemahaman tidak murni tercipta begitu saja, tetapi selalu diwarnai oleh sejarah dan masyarakat, karena itu sejarah tidak bisa dilepaskan dari masa sekarang (Rahardjo, 1995)

Dari teori di atas kita dapat mengatakan bahwa: pertama, teks adalah sesuatu yang tidak muncul tanpa sebab. Atau ada sesuatu yang menyebabkan mengapa sebuah teks tersebut muncul. Kedua, dalam memahami sebuah teks, seseorang tidak bisa secara spontan memaknai teks itu tanpa dipengaruhi oleh unsur-unsur lain di luar dirinya. Unsur pengalaman, sejarah dan tradisi masyarakat, sangat berpengaruh terhadap diri seseorang ketika dia memahami sebuah teks.

Al-Qur'an adalah teks. Kita sebut demikian, karena isi Al-Qur'an, sebagai kitab suci, bisa kita kategorikan ke dalam ciri-ciri sebuah teks. Isi dalam suatu teks tidak lain adalah bahasa dan $\mathrm{Al}-$ Qur'an adalah bacaan yang mengandung bahasa. Dalam tinjauan hermeneutik, bahasa dapat dipelajari bukan hanya sekedar sebagai sistem tanda atau bentuk-bentuk kalimat, tetapi juga sebagai runtutan panjang wacana tertulis yang disebut teks. Peralihan dari suatu kalimat ke teks adalah peralihan dari wilayah semantik memasuki wilayah hermeneutik; problemproblem baru yang timbul dan isu-isu tertentu yang muncul dalam wilayah semantik semuanya dilampaui dan berubah. (Thompson: 2003, 284)

Sebagai sebuah teks, Al-Qur'an tidak hanya dipandang sebagai sebuah benda yang mati. Tetapi dia akan difahami oleh orang dari berbagai macam sudut pandang yang berbeda. Menurut Gadamer, ketika menafsirkan suatu teks, seseorang akan menggunakan sejumlah instrumen seperti bahasa, metodologi, filsafat, sejarah dan tradisi masyarakat, yang akan membantunya mendapatkan penafsiran yang paling dekat kepada kebenaran menurut penafsirnya. Penafsiran terhadap teks muncul karena keterbatasan teks tersebut dalam mengakomodasikan diri terhadap situasi dan kondisi yang ada. Maka dari itu untuk menghidupkan kembali semangat yang terkandung dalam teks itu, para penafsir menafsirkannya kembali agar sesuai dengan keadaan di mana teks tersebut berada .

Pandangan Gadamer ini, telah membuktikan adanya kebenaran teoritis untuk menjelaskan mengapa pergeseran paradigma tafsir perempuan dalam konteks Indonesia kontemporer ini terjadi. Pertama, dalam menyelami sebuah teks, para mufassir Indonesia itu telah menggali makna teks dengan mempertimbangkan horison-horison yang melingkupi teks tersebut, yaitu horison teks itu sendiri, horison pengarang dan horison pembaca. Kedua, di samping memperhatikan horisonhorison tersebut mereka juga berusaha melahirkan kembali makna tersebut sesuai dengan situasi dan kondisi saat teks tersebut dibaca atau dipahami. Munculnya paradigma klasik misalnya, sangat dipengaruhi oleh situasi politik, budaya dan social bangsa Indonesia pada saat itu yang masih berada di bawah tekanan para penjajah. Meskipun masa ini berlanjut hingga Indonesia telah merdeka, tetapi bekasbekas penjajahan masih melekat kuat dalam diri bangsa Indonesia. Pandangan dunia bangsa Indonesia pada saat itu sangat paternalistic dan belum banyak tokoh wanita muslimah yang memiliki peran dalam masyarakat. Karenanya, penafsiran para mufassir pada saat itu juga bersifat paternalistic dan sangat berpihak kepada kaum laki-laki.

Sementara itu, pada paradigma modern, kondisi bangsa Indonesia telah mengalami sedikit kemajuan. Kajian keislaman di kalangan cendekiawan Muslim Indonesia telah mengalami perkembangan yang menggembirakan. Berbagai macam seminar, konferensi dan diskusi ilmiah tentang reaktualisasi Islam, hukum Islam, pendidikan Islam dan sebagainya digelar, baik di kampus-kampus maupun pesantren. Literatur- 
literatur tentang pembaharuan pemikiran Islam pun bermunculan bak jamur yang tumbuh pada musim hujan. Keadaan semacam ini menjadikan diskusi keislaman dan kemoderenan sejak masa pertengahan Orde Baru lebih semarak. Pikiranpikiran segar tentang keislaman banyak dilontarkan oleh kaum intelektual, baik dalam bidang fiqih, hadits, maupun tafsir. Menurut Martin (95: 112) pada saat ini, tulisan-tulisan para modernis Islam, khususnya dari Timur Tengah seperti M. Abduh, Rasyid Ridha dan para pemikir Islam mutakhir seperti al-Jabiri, Rahman, dan sebagainya tidak masuk dalam kurikulum pesantren dan tidak dijadikan sebagai literatur resmi untuk diajarkan. Pemikiran para tokoh modernis tersebut, berpengaruh terhadap penafsiran terhadap ayat-ayat perempuan, hingga menjadikan kedudukan perempuan disetarakan dengan laki-laki dalam beberapa hal, meskipun dalam hal-hal tertentu masih dibedakan.

Sementara itu, munculnya paradigm Neomodern seiring dengan munculnya era keterbukaan di Indonesia. Menurut Heirussalim (1999), terbukanya arus demokrasi di Indonesia, telah membuka babak baru dalam bidang politik, social dan budaya. Sekitar 48 partai ikut dalam pesta pemilu 7 Juli 1998. Di antara 48 partai politik yang ada, sepertiga di antaranya berazazkan pada agama Islam. Sementara itu, dunia pendidikan Islam, di tengah carutmarutnya situasi politik dan krisis ekonomi tersebut, tetap berjalan sebagaimana biasanya. Akan tetapi ada di antara Madrasah-madrasah swasta dan pondok pesantren yang mengalami kesulitan keuangan apalagi untuk pengembangan fisik. Sementara Madrasah negeri dan Perguruan Tinggi Islam negeri (IAIN) tetap berjalan baik. Perkembangan literatur keislaman, khususnya dalam bidang tafsir, hadits, fiqih dan sebagainya juga banyak mangalai kemajuan. Belum lagi muncul gerakan feminism dan gender di Indoensia yang menuntut agar perempuan disejajarkan dengan laki-laki. Kondisi semacam ini, menjadikan para mufassir berusaha meninjau ulang penafsiran terhadap ayat-ayat perempuan, sehingga sesuai dengan situasi dan kondisi masyarakat yang berkembang pada saat itu.

Jadi, ditinjau dari hermeneutika Gademerian, alQur'an yang dipandang sebagai teks, sangat terbuka untuk diinterpretasikan, baik dari sisi hukum, filsafat, sejarah dan sebagainya, karena sebagai teks, Al-Qur'an tidak bisa lepas dari unsur-unsur tersebut. Untuk itu, interpretasi terhadap Al-Qur'an juga sangat memungkinkan terjadinya perbedaan karena kemampuan dan situasi-kondisi penafsir yang berbeda. Dalam kasus gender dan masalah perempuan, seperti yang dijelaskan di atas, perbedaan itu dapat terlihat dengan jelas. Di mana telah terjadi pergeseran paradigma dalam tafsir tentang perempuan, dari penafsiran yang berparadigma tradisional, paradigma modern, hingga akhirnya paradigma neo-modern. Akan tetapi, ketiga paradigma tersebut bukan merupakan sebuah paradigma yang berdiri sendiri-sendiri, melainkan merupakan sebuah proses panjang dari perjalanan tafsir yang berkembang dari waktu ke waktu.

\section{Penutup}

Dari seluruh rangkaian penjelasan di atas maka terbuktilah hipotesa awal yang mengatakan bahwa studi-studi tafsir tentang perempuan di Indonesia telah mengalami perkembangan yang pesat, dari penafsiran tradisional yang kurang memperhatikan kondisi sosia kulturan dan tantangan modernitas, menjadi penafsiran yang sangat memperhatikan sosio-kultural dan modernitas-juga referensi wacana feminismesehingga memungkinkan adanya pergeseran paradigma yang berbeda dengan tafsir Arab kalsik sebelumnya.

Pembuktian hipotesa ini diukur melalui empat unsur utama; yaitu dari sisi metodologis, pendekatan, daya adaptasinya dengan modernitas dan pandangan dunianya terhadap masalah perempuan. Berdasarkan keempat parameter ini dapat disimpulkan bahwa paradigm tafsir perempuan di Indonesia telah mengalami tiga macam pergeseran paradigma, yaitu paradigma tradisional, paradigma modern, dan paradigma neo modern.

Adanya pergeseran paradigma dalam tafsir perempuan ini disebabkan karena beberapa faktor seperti faktor social, budaya, politik, dan sebagainya yang melingkupi para penafsir. Semakin komplek masalah yang dihadapi oleh penafsir di zaman yang dihadapinya, maka akan berbeda corak penafsirannya dengan penafsir di zaman yang lebih homogen secara social atau situasi politik yang berbeda juga berpengaruh terhadap hasil penafsiran tersebut. Namun sejalan dengan apa yang dikatakan oleh Hasan Hanafi bahwa penafsiran mereka tidak ada yang benar atau salah. Yang terjadi pada tiga paradigma tafsir perempuan itu adalah karena ketiganya memiliki metode, pendekatan, cara pandang dan kepentingan yang berbeda, sehingga mempunyai pandangan dunia yang berbeda pula. Semua paradigma di atas memiliki kebenarannya sendiri-sendiri tanpa harus mengatakan mana yang salah dan mana yang benar. Semua penafsiran itu memiliki kebenaran 
pada konteks dunianya sendiri-sendiri. Perbedaan pendapat tersebut muncul karena perbedaan kondisi sosial, adat-istiadat, dan kecenderungan masing-masing, yang kemudian mempengaruhi cara pandanga dan kesimpulan merek adalam menafsirkan ayat-ayat Al-Qur'an.

Temuan tulisan ini mendukung tesis dasar yang diajukan oleh Gadamer yang bersikukuh bahwa tidak bisa ada pemahaman tunggal terhadap apa yang dikemukakan seorang produsen wacana. Bagi masyarakat interpretif yang berbeda situasi, kondisi dan kepentingan, produsen wacana dalam istilah Gadamer- benar-benar telah mati. Wacana apa pun yang dibangun oleh produsen wacana -dalam hal ini adalah Allah sebagai sumber wahyu- niscaya ditafsirkan dengan berbeda dan kadang "semena-mena" oleh masyarakat interpretif yang tidak berkesamaan kepentingan.

\section{DAFTAR PUSTAKA}

Agustina, Nurul. 1994. Tradisionalisme Islam dan Feminisme. Jurnal Ulumul Qur'an edisi khusus no. 5 dan 6 vol. 5 .

Anwar, M. Syafi'i. 1995. Pemikiran dan Aksi Islam Indonesia. Jakarta: Paramadina Mulia.

Baidan, Nashruddin. 1999. Tafsir bi ar-Ra'yi: Upaya Penggalaian Konsep Wanita dalam Al-Qur'an. Yogyakarta: Pustaka Pelajar.

Fasya, Teuku Kemal. 2002. “Semiotika dan Martabat Sebuah Tulisan”. Kompas, 1 November: 43.

Fay, Brian. 1996. Contemporary Philosophy of Social Science. Oxford: Blackwell.

Gadamer, Hans-Georg. 1975. Truth and Method. New York: The Seaburv Press.

Gadamer, Noels-Georg. 1977. Philosophical Hermeneutic. Translated and Edited by David E.

Hamka. 1982. Tafsir Al-Azhar. Bandung: Bulan Bintang.

Littlejohn, Stephen W. 1992. Theories of Human Communication. Belmont, California: Wadsworth Publishing Company.

Nasaruddin. 1999. Argumen Kesetaraan Gender. Bandung: Mizan.

Rahardjo, Mudjia. 1995. Mengapa Gusdur Jatuh: Suatu Kajian Bahasa dalam Wacana Politik. Surabaya: Lutfansah Media Utama.

Stowasser, Barbara. 1998. "Gender Issues and Contemporary Qur'an Interpretation", dalam Yuanne Yazbeck Haddad dan John L. Esposito, Islam, Gender and Social Change. New York: Oxford University Press, 1998.

Syafruddin, Didin. 1994. "Argumen Supremasi Atas Perempuan: Penafsiran Klasik QS. Al-Nisa':34, dalam Jurnal Ulumul Qur'an, Edisi Khusus, no. 5 \& 6, Vol.5.

Syarifuddin, Didin. 1994. “Argumen Supremasi atas Perempuan: Penafsiran Klasik Q.S. Al-Nisa': 34". Jurnal Ulumul Qur'an, Edisi khusus -No. 5\&6, Vol. V.

Syihab, M. Qurais. 2002. Membumikan Al-Qur'an: Fungsi dan Peran Wahyu dalam Kehidupan Masyarakat. Bandung: Mizan.

Thiselton, Anthony C. 1992. New Horizons in Hermeneutics. Michigan: Zondervan Publishing House.

Thompson, John B. 1990. Critical Hermeneutics: A Study in the Thaouth of Paul Ricouer and Jurgen Haberman. Cambridge: Cambridge University Press.

Umar, Nasaruddin Umar, M.A. 1999. Argumen Kesetaraan Gender Perspektif Al-Qur'an. Jakarta: Paramadina Mulia.

Umar, Nasaruddin. 1999. Argumen Kesetaraan Gender Perspektif Al-Qur'an. Jakarta: Paramadina Mulia. 
LFGUA Volume 5, Nomor 2, Desember 2010 - ISSN 1693-4725

Yunus, Mahmud. 1993. Tafsir Qur'an Karim. Jakarta: Departemen Agama Islam.

Zarkasyi, Hamid Fahmy. 2004. "Menguak Nilai Dibalik Hermeneutika”. ISLAMIA. Tahun 1. No. I/Muharram 1425. 